
\title{
Reseacch Soute \\ Binding effects of Alpinia galanga oil and its nanoemulsion 1 to GABAA receptors in rat cortical membranes
}

Nattakanwadee Khumpirapang

Naresuan University

Krit Suknuntha

Prince of Songkla University

Songyot Anuchapreeda

Chiang Mai University

Petrine Wellendorph

University of Copenhagen

Anette Müllertz

University of Copenhagen

Thomas Rades

University of Copenhagen

Siriporn Okonogi ( $\nabla$ okng2000@gmail.com )

Chiang Mai University

\section{Research Article}

Keywords: anesthetic, binding, methyl, eugenol, activity, been, gabaa

Posted Date: August 31st, 2021

DOl: https://doi.org/10.21203/rs.3.rs-816924/v1

License: (c) (1) This work is licensed under a Creative Commons Attribution 4.0 International License.

Read Full License 


\section{Binding effects of Alpinia galanga oil and its nanoemulsion to $\mathrm{GABA}_{A}$ receptors in rat cortical membranes}

\section{Nattakanwadee Khumpirapang ${ }^{1}$, Krit Suknuntha ${ }^{2}$, Songyot Anuchapreeda ${ }^{3,4}$, 4 Petrine Wellendorph ${ }^{5}$, Anette Müllertz ${ }^{6}$, Thomas Rades ${ }^{6}$, and Siriporn Okonogi ${ }^{4,7, *}$}

${ }^{1}$ Department of Pharmaceutical Chemistry and Pharmacognosy, Faculty of Pharmaceutical Sciences, Naresuan University, Phitsanulok 65000, Thailand

${ }^{2}$ Department of Pharmaceutical Chemistry, Faculty of Pharmaceutical Sciences, Prince of Songkla University, Songkhla 90112, Thailand

${ }^{3}$ Department of Medical Technology, Faculty of Associated Medical Sciences, Chiang Mai University, Chiang Mai 50200, Thailand

${ }^{4}$ Research Center of Pharmaceutical Nanotechnology, Faculty of Pharmacy, Chiang Mai University, Chiang Mai 50200, Thailand

${ }^{5}$ Department of Drug Design and Pharmacology, Faculty of Health and Medical Sciences, University of Copenhagen, Copenhagen 2100, Denmark.

${ }^{6}$ Department of Pharmacy, Faculty of Health and Medical Sciences, University of Copenhagen, Copenhagen 2100, Denmark

${ }^{7}$ Department of Pharmaceutical Sciences, Faculty of Pharmacy, Chiang Mai University, Chiang Mai 50200, Thailand

*Corresponding author Email: okng2000@gmail.com

\section{Abstract}

Anesthetic activity of Alpinia galanga oil (AGO) has been reported however the mechanism of action in mammals has not been clear. In the present study, the binding effects of AGO and its three active components to gamma-aminobutyric acid type $A\left(G A B A_{A}\right)$ receptor in cortical membranes of Sprague-Dawley rats were firstly investigated using a $[3 \mathrm{H}]$ muscimol binding assay. Dimethyl sulfoxide (DMSO) was used to deliver these test samples. The results showed that only AGO and methyl eugenol displayed positive modulation at the highest concentration whereas 1,8 cineole and 4-allylphenyl acetate were inactive. An oil-in-water nanoemulsion containing $20 \% \mathrm{w} / \mathrm{w}$ AGO (NE-AGO) was formulated to deliver AGO instead of DMSO. This NE-AGO significantly enhanced a specific [3H]muscimol binding to $179 \%$ of the control with $\mathrm{EC}_{50}$ of $391 \mu \mathrm{g} / \mathrm{mL}$. The result correlates well to the amount of methyl eugenol in AGO. This result confirms that the anesthetic activity of $A G O$ and methyl eugenol is associated with $\mathrm{GABA}_{\mathrm{A}}$ receptor modulation, while that of 1,8-cineole and 4-allylphenyl acetate is not and may instead be related to other mechanisms. AGO showed well-tolerated by human cells. Therefore, the formulated NE-AGO might be a promising alternative anesthetic product for humans.

\section{Introduction}

Alpinia galanga is an edible plant of the Zingiberaceae family which is widely cultivated in Southeast Asian countries ${ }^{1,2}$. A. galanga is well-known in Asian folk medicine and has been used for centuries as a food additive, an antimicrobial agent, a local anesthetic, an analgesic, and an antipruritic ${ }^{3-6}$. A. galanga oil (AGO) is rich in 1,8-cineole and 4-allylphenyl acetate ${ }^{7}$. AGO was recently shown to act as an anesthetic in fish ${ }^{8}$. Further, 1,8-cineole has been shown to reduce locomotor activity in rodents when administered orally or intraperitoneally ${ }^{9,10}$. To the best of our knowledge, the mechanism of anesthetic action of AGO 
has not yet been elucidated. Moreover, 4-allylphenyl acetate has not been reported for anesthetic effect in rodents, whereas methyl eugenol, a minor compound of AGO has been reported as a surgical anesthetic in rodents ${ }^{11}$.

Generally, anesthetics have been used to relieve pain and suffering during surgery and post-surgery by inhibiting or depressing propagation of the signal along the nerves ${ }^{12}$. The mechanism of action of these anesthetics are a blockade of the N-methyl-D-aspartate receptor receptors, inhibition of dopaminergic receptors, or enhancement of the function of $\gamma$-aminobutyric acid type $\mathrm{A}\left(\mathrm{GABA}_{\mathrm{A}}\right)$ receptors ${ }^{13}$. In addition, $\mathrm{GABA}_{\mathrm{A}}$ receptors are the principal ionotropic receptors for fast inhibitory neurotransmission in the mammalian central nervous system ${ }^{14}$. $\mathrm{GABA}_{\mathrm{A}}$ receptors are clinically employed targets for a range of structurally diverse positive allosteric modulators such as isoflurane, etomidate, propofol, barbiturates, and benzodiazepines ${ }^{15-17}$. Given the structural resemblance of the main AGO constituents with myristicin, another previously reported $\mathrm{GABA}_{\mathrm{A}}$ receptor positive allosteric modulators ${ }^{18}$ (Fig. 1), we hypothesized that the anesthetic mechanism of action of $\mathrm{AGO}$ involves central $\mathrm{GABA}_{\mathrm{A}}$ receptors.

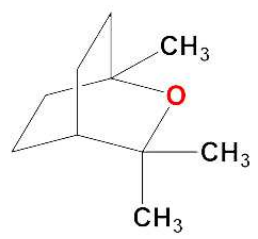

c

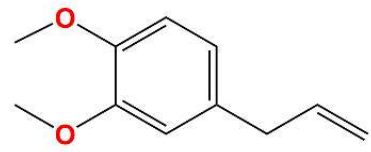

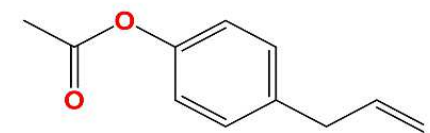

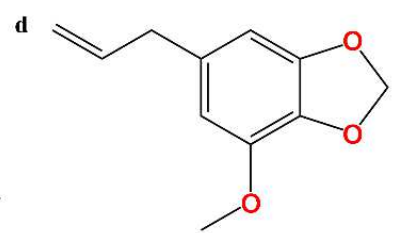

Figure 1. Chemical structures of 1,8-cineole (a), 4-allylphenyl acetate (b), methyl eugenol (c), and myristicin $(d)$.

The poor water-solubility of active compounds in essential oils remains a challenge in bioassay studies employing aqueous buffers. To overcome this problem, many organic solvents have been used for dissolving or delivery the active compounds before activity testing, however, potentially compromising the biological evaluation ${ }^{19}$. AGO is also water-insoluble, therefore it needs a potential delivery system for solubility enhancement. Nanoemulsion is one of the promising nano delivery system that can improve aqueous solubility of many hydrophobic active compounds ${ }^{20-22}$. The nanoemulsions of several waterinsoluble compounds have been developed for using in various bioassay studies ${ }^{23-26}$.

In the present study, the chemical components of AGO extracted from the fresh rhizomes of A. galanga were analyzed. AGO and its three selected chemical components, 1,8-cineole, 4-allylphenyl acetate, and methyl eugenol were investigated for the possible mechanism of action on anesthetic activity in mammals using rat brain $\mathrm{GABA}_{\mathrm{A}}$ receptors. Moreover, a nanoemulsion containing AGO (NE-AGO) was formulated to reduce the amount of organic solvent used for dissolving AGO and to investigate for its potential on AGO delivery. The toxicity of AGO on normal human cells was also investigated for the further studies of NE-AGO in humans.

\section{Results and Discussion}

Extraction and chemical analysis of AGO. AGO appeared as a clear pale yellowish liquid. The chromatograms of AGO obtained from gas chromatography-mass spectrometry (GC-MS) demonstrated 14 identifiable chemical components that represented $97.93 \%$ of the total chemical components of AGO (Table 
1). The main chemical components of AGO were 1,8-cineole (41.94 $\pm 0.13 \%)$, 4-allylphenyl acetate (35.70 $\pm 0.14 \%)$, and methyl eugenol $(3.23 \pm 0.02 \%)$, respectively. The identified chemical components of AGO are similar to what has been found in a previous study ${ }^{8}$. However, the percent content of these components was slightly different. Changes in composition of essential oils from the same plants are sometimes found due to harvest period or post-harvest air drying periods of the plants ${ }^{27,28}$.

\begin{tabular}{|l|l|l|l|}
\hline No. & Components & Retention time (min) & Amount (\%) \\
\hline 1 & $\beta$-Pinene & 5.08 & $0.72 \pm 0.07$ \\
\hline 2 & 1,8 -Cineole & 6.62 & $41.94 \pm 0.13$ \\
\hline 3 & $\alpha$-Terpineol & 11.49 & $2.64 \pm 0.06$ \\
\hline 4 & Terpinen-4-ol & 11.89 & $3.07 \pm 0.04$ \\
\hline 5 & Chavicol & 15.85 & $1.33 \pm 0.08$ \\
\hline 6 & 4-Allylphenyl acetate & 19.02 & $35.70 \pm 0.14$ \\
\hline 7 & Geranyl acetate & 20.40 & $0.55 \pm 0.01$ \\
\hline 8 & Methyl eugenol & 21.39 & $3.23 \pm 0.02$ \\
\hline 9 & $\alpha$-Farnesene & 22.32 & $0.58 \pm 0.05$ \\
\hline 10 & $\beta$-Bisaboloene & 25.29 & $0.78 \pm 0.01$ \\
\hline 11 & $\beta$-Sesquiphellandrene & 25.87 & $0.53 \pm 0.01$ \\
\hline 12 & Eugenyl acetate & 26.22 & $1.19 \pm 0.02$ \\
\hline 13 & 9-Octadecenoic acid & 44.86 & $2.34 \pm 0.12$ \\
\hline 14 & 9-Octadecenamide & 46.53 & $3.39 \pm 0.07$ \\
\hline \multicolumn{2}{|l|}{ Total } & $97.99 \pm 0.34$ \\
\hline
\end{tabular}

Table 1. Chemical components in AGO.

95

Preparation and characterization of NE-AGO. As AGO is immiscible with water, DMSO is always used to dissolve AGO and enhance water miscibility. However, DMSO shows several disadvantages due to its toxic effects to animals and humans and binding interferences. Nanoemulsions can be prepared without the use of organic solvents ${ }^{29}$. Incorporation of water-insoluble drugs into the $\mathrm{o} / \mathrm{w}$ nanoemulsions can improve their water miscibility ${ }^{30}$. In the present study, NE-AGO was formulated without the use of organic solvent to improve the aqueous miscibility of AGO and to avoid any binding interference of DMSO in the employed binding assay. It was found that the formulated NE-AGO containing 20\%w/w AGO appeared as a translucent mixture with white-bluish color and showed no phase separation. It was found that after adding the NE-AGO with water to make a 100 -fold dilution, a fast-dispersing time of the formulation with less than 5 min was observed. Moreover, the small droplet size of $49 \pm 2 \mathrm{~nm}$ of AGO was obtained with a size distribution expressed as polydispersity index (PDI) of only $0.24 \pm 0.01$. The small PDI score indicated that this formulation presented a narrow droplet size distribution. The size distribution curve showed a single peak, and the peak intensity of this formulation was $99.8 \%$ (Fig. 2). Zeta potential of the diluted NE-AGO was negative with a value of $-14.4 \pm 0.6 \mathrm{mV}$. Adsorption of hydroxyl ions in the aqueous system onto the surface of the droplets may leads to slightly negative zeta potential value, and may be the explanation of the negative zeta-potential of this formulation ${ }^{31,32}$.

$\left[{ }^{3} \mathrm{H}\right]$ Muscimol binding studies. $\left[{ }^{3} \mathrm{H}\right]$ Muscimol was used as a high-affinity radioligand to label $\mathrm{GABA}_{\mathrm{A}}$ receptors in a synaptosomally enriched cortical homogenate preparation from Sprague-Dawley rats as previously reported ${ }^{33}$. AGO at a concentration of $1 \mathrm{mg} / \mathrm{mL}$ (in DMSO) showed specific modulation of $\left[{ }^{3} \mathrm{H}\right]$ muscimol at $130 \%$ similar to diazepam (positive control) at a concentration of $100 \mu \mathrm{M}$ (Fig. 3a), in 
accordance with other reports ${ }^{34,35}$. These binding results indicate that AGO has constituents able to modulate $\left[{ }^{3} \mathrm{H}\right]$ muscimol binding, which is prompting further studies. These involved testing of the three main constituents; 1,8-cineole, 4-allylphenyl acetate, and methyl eugenol, from AGO, and indicated that only methyl eugenol was a modulator. A similar specific modulate $\left[{ }^{3} \mathrm{H}\right]$ muscimol binding of AGO and methyl eugenol was according to the different concentrations used in the test. The concentration of methyl eugenol used (i.e. $100 \mu \mathrm{M}$ ) is about 55-folds higher than that of methyl eugenol actually found in AGO (3.23\%). Moreover, the concentration of 1,8-cineole (42\%) and 4-allylphenyl acetate (36\%) used, are also 3.6 and 4.9 folds higher than the actual amount found in AGO. Thus, the result showed that the modulate $\left[{ }^{3} \mathrm{H}\right]$ muscimol binding of these compounds was similar to that of AGO at $10 \mu \mathrm{g} / \mathrm{mL}$.

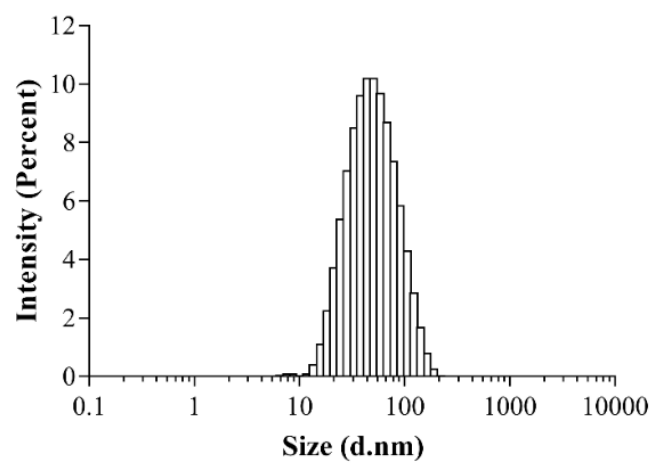

Figure 2. Size distribution of NE-AGO.

In this study, DMSO was used for dissolving AGO and its components, therefore, DMSO was also tested separately. It was shown that DMSO significantly decreased the specific binding of $\left[{ }^{3} \mathrm{H}\right]$ muscimol at concentrations above $3 \% \mathrm{w} / \mathrm{w}$, limiting the accuracy of the compound testing above $300 \mu \mathrm{M}$. Thus, an accurate assessment of $\mathrm{EC}_{50}$ values could not be obtained from the oil or methyl eugenol containing DMSO. Moreover, DMSO at a concentration above $1 \% \mathrm{w} / \mathrm{w}$ dissolved the membrane while the nanoemulsion did not. To improve aqueous solubility and precluding the use of DMSO, the NE-AGO was instead used for testing. The binding effect of blank NE-AGO (the nanoemulsion without AGO) as a negative control at the highest tested concentration was not significantly different from $100 \%$ binding, indicated that the excipient itself did not significantly modulate binding levels (Fig. 3b). Instead, the $\mathrm{EC}_{50}$ value, potent agonist value $\left(\mathrm{pEC}_{50} \pm\right.$ S.E.M.), and maximum binding levels (mean \pm S.E.M.) of AGO was obtained in the NE-AGO formulation described and found to be $391 \mu \mathrm{g} / \mathrm{mL}(3.41 \pm 0.02)$ and $179 \pm 10 \%$ of the control.

Cytotoxicity study of AGO on human normal cells. Cytotoxicity studies often use peripheral blood mononuclear cells (PBMCs) as model cells for assessing the inhibitory effects of chemicals on cell proliferation of human normal cells ${ }^{36,37}$. Thus, PBMCs were used to evaluate cytotoxicity in this study. The dose-response curves showed high viability of PBMCs (> 80\%) after exposure to AGO in DMSO at all contact times and concentrations (Fig. 4). Normally, PBMC viability values higher than $80 \%$ are regarded as safe for human use ${ }^{38}$. In addition, the $\mathrm{IC}_{50}$ values of $\mathrm{AGO}$ in DMSO at all contact times were higher than $500 \mu \mathrm{g} / \mathrm{mL}$. There was no significant difference in the concentration and contact time of AGO in DMSO on the viability of PBMCs among the groups exposed to AGO in DMSO for 1, 3, 6, 12, and 24 $\mathrm{h}(p<0.05)$. However, the toxicity profile of PBMCs exposed to AGO in DMSO for $48 \mathrm{~h}$ showed concentration-dependency $(p<0.01)$. These results indicated that AGO had no cytotoxic activity on PBMCs. The cell viability was higher than $90 \%$ when the blank NE-AGO at a final concentration of 500 $\mu \mathrm{g} / \mathrm{mL}$ was used, indicating the non-toxicity of the blank NE-AGO. 
Figure 3. Modulation of $\left[{ }^{3} \mathrm{H}\right]$ muscimol binding to rat brain cortical homogenate. The $100 \%$ binding (dashed red line) denotes the total specific binding by $30 \mathrm{nM}\left[{ }^{3} \mathrm{H}\right]$ muscimol (a). Data are presented as mean percentage of specific binding \pm S.E.M. (b). Red point indicates the blank NE-AGO vehicle at the highest concentration. Asterisk $\left(^{*}\right)$ indicates significant differences between groups with $100 \%$ binding $(p<0.05)$.
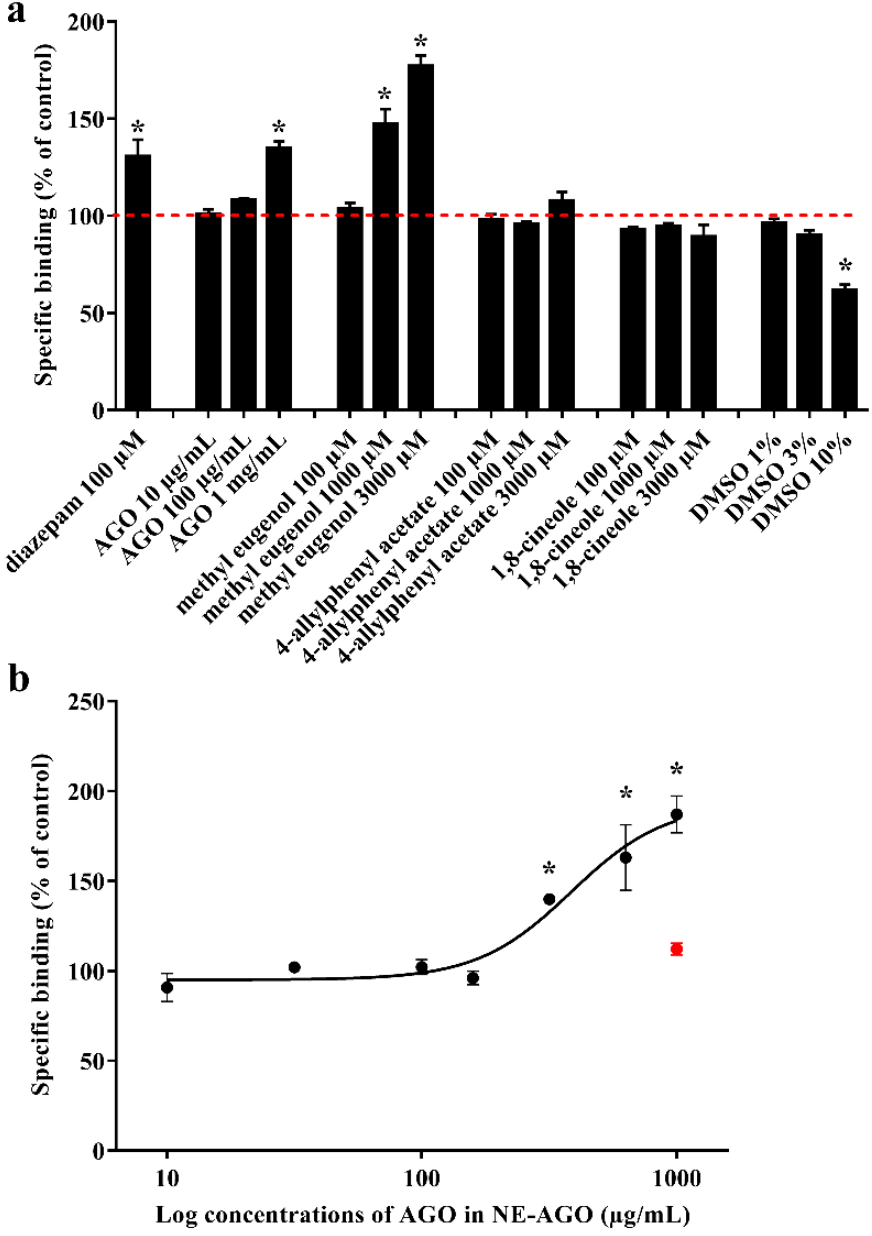

b

$\mathrm{GABA}_{\mathrm{A}}$ receptors are the most common targets for general anesthetics. However, general anesthesia can be induced via other pathways such as enhancing inhibitory signals or blocking excitatory signals. Generally, anesthetics act as $\mathrm{GABA}_{\mathrm{A}}$ receptor agonists, N-methyl-D-aspartate receptor antagonists, $\alpha 2$ Adrenoceptor agonists, or dopaminergic receptor antagonists. In the present study, $\mathrm{GABA}_{\mathrm{A}}$ receptors were emphasized due to their being the most common target. The anesthetic activity of AGO could potentially be due to methyl eugenol via the involvement of $\mathrm{GABA}_{\mathrm{A}}$ receptors ${ }^{39}$, while the activity of 1,8 -cineole and 4-allylphenyl acetate might be related to other mechanisms. There is no correlation between the constituent content and the mechanism. However, The $\mathrm{EC}_{50}$ and maximal binding levels of the NE-AGO formulation are correlates well to the measured content of methyl eugenol present in this essential oil $(180 \mu \mathrm{M})$. The results confirmed that the anesthetic activity of AGO could potentially be due to methyl eugenol via the involvement of $\mathrm{GABA}_{\mathrm{A}}$ receptors. 

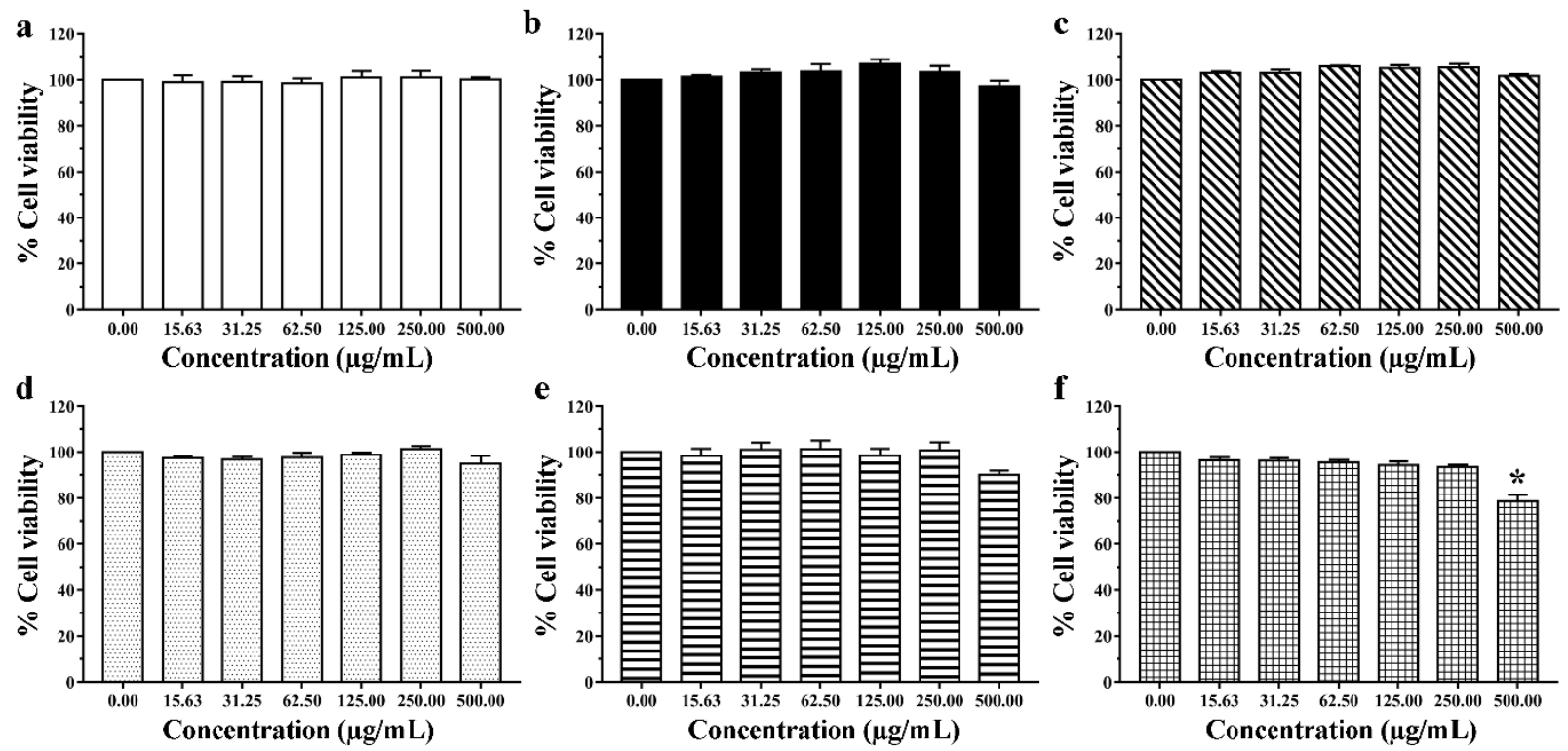

Figure 4. Dose-response curves of viability of PBMCs exposed to AGO in DMSO for $1 \mathrm{~h}$ (a), $3 \mathrm{~h}$ (b), $6 \mathrm{~h}$ (c), $12 \mathrm{~h}(\mathrm{~d}), 24 \mathrm{~h}(\mathrm{e})$, and $48 \mathrm{~h}(\mathrm{f})$. Data are presented as means \pm S.E.M. and were analysed based on a one-way ANOVA followed by Tukey's post-hoc test $(p<0.05)$. Asterisk $(*)$ indicates significant differences between concentrations of AGO.

\section{Conclusions}

Among AGO and its three main compounds, methyl eugenol, 1,8-cineole, and 4-allylphenyl acetate, it can be concluded that the possible anesthetic mechanism of action of AGO and methyl eugenol is associated with $\mathrm{GABA}_{\mathrm{A}}$ receptor modulation. The activity of 1,8-cineole and 4-allylphenyl acetate is not due to $\mathrm{GABA}_{\mathrm{A}}$ receptor modulation and might instead be related to other mechanisms. AGO is well-tolerated by human cells. Nanoemulsion is a good delivery system for AGO. NE-AGO might be useful as an alternative anesthetic nanoformulation for further studies in humans.

Materials. Fresh rhizomes of A. galanga were collected from the medicinal plant garden of Chiang Mai University, Chiang Mai, Thailand in February 2018 according to WHO Guidelines on Good Agricultural and Collection Practices (GACP) for Medicinal Plants. The plant was identified by Wannaree Charoensup (a botanist, Department of Pharmaceutical Sciences, Faculty of Pharmacy, Chiang the Northern Research Center for Medicinal Plants, Faculty of Pharmacy, Chiang Mai University, Thailand. 
Fetal bovine serum (FBS), penicillin, streptomycin, L-glutamine, and RPMI 1640 were purchased from GIBCO InvitrogenTM (Waltham, MA, USA). Lymphoprep and 4-allylphenyl acetate were purchased from Axis-Shield PoC AS (Oslo, Norway) and ABCR GmbH (Karlsruhe, Germany). Methyl eugenol, 3(4,5-Dimethylthiazol-2-yl)-2,5-diphenyltetrazolium bromide (MTT) and DMSO were from Sigma-Aldrich (St Louis, MO, USA). 1,8-cineole, polyoxyethylene sorbitan monooleate (Tween 80), phosphate buffer solution (PBS), and dichloromethane were of analytical grade and supplied by Merck Millipore (Darmstadt, Germany). Diazepam and $\left[{ }^{3} \mathrm{H}\right]$ muscimol $(36.6 \mathrm{Ci} / \mathrm{mmol})$ were obtained from Nycomed Danmark A/S (Hobro, Denmark) and Perkin Elmer (Boston, MA, USA).

Extraction and chemical analysis of AGO. Fresh rhizomes of A. galanga were washed with clean water and cut into small pieces before subjecting to hydro-distillation for $3 \mathrm{~h}$. The obtained AGO was analyzed for their chemical compositions by GC-MS on an Agilent 6890 gas chromatograph coupled to electron impact (EI, $70 \mathrm{eV}$ ) using a Hewlett Packard (HP) mass selective detector (MSD), model HP 5973MSD (Agilent Technologies Inc, USA). The HP5-MSI column; $30.0 \mathrm{~m} \times 0.25 \mathrm{~mm}$ i.d. $\times 0.25 \mu \mathrm{m}$ film thickness (Agilent Technologies Inc, USA) was used as a capillary column. The analytical conditions were modified from a previous study ${ }^{41,42}$. Briefly, AGO was diluted with dichloromethane to $1: 100(\mathrm{v} / \mathrm{v})$ and 1 $\mu \mathrm{L}$ of this mixture was injected into GC-MC. The injection and detector temperatures were $250^{\circ} \mathrm{C}$ and $280^{\circ} \mathrm{C}$, respectively. The oven temperature was $70^{\circ} \mathrm{C}$. The sample was held isothermally for 3 min and the temperature was then increased at $3^{\circ} \mathrm{C} / \mathrm{min}$ to $188^{\circ} \mathrm{C}$, and then at $20^{\circ} \mathrm{C} / \mathrm{min}$ to $280^{\circ} \mathrm{C}$, followed holding for $3 \mathrm{~min}$. Helium was used as carrier gas at a flow rate of $1 \mathrm{~mL} / \mathrm{min}$. The experiments were performed in triplicate with at least three independent experiments.

Preparation and characterization of NE-AGO. NE-AGO composed of $20 \% \mathrm{w} / \mathrm{w}$ AGO, 10\%w/w Tween 80 , and $70 \% \mathrm{w} / \mathrm{w}$ water was prepared according to a method previously described as it was reported that NE-AGO formulated by this method was chemically stable when stored at various temperatures $\left(4^{\circ} \mathrm{C}\right.$, $20^{\circ} \mathrm{C}$, and $\left.40^{\circ} \mathrm{C}\right)$ for several weeks $(0,4,8,12 \text { weeks })^{7}$. Briefly, the aqueous phase composed of Tween 80 and water was mixed using a vortex mixer for $5 \mathrm{~min}$. The oil phase was composed of AGO. The water phase was added to the oil phase under stirring at $50^{\circ} \mathrm{C}$ for $5 \mathrm{~min}$ before subjecting to a high-speed stirring of 16,000 rpm using an Ultra-Turrax T25 (Janke and Kunkel GmbH, Germany) for 5 min and passed through a high-pressure homogenizer (Avestin Inc., Canada) under a pressure of 10,000 psi for 7 cycles at room temperature.

The droplet size, size distribution, and zeta potential of the obtained NE-AGO were determined using dynamic light scattering by photon correlation spectroscopy (Zetasizer Nano ZS, Malvern Instruments Ltd., UK). The PDI value indicates the width of the size distribution. The size measurements were obtained by averaging at least ten measurements at a fixed angle of $173^{\circ}$ at $25^{\circ} \mathrm{C}$. NE-AGO was diluted $(1: 100 \mathrm{v} / \mathrm{v})$ with purified water to have a suitable scattering intensity before measurement. The experiments were carried out in triplicate with at least three independent experiments.

$\left[{ }^{3} \mathrm{H}\right]$ muscimol binding assay. Rat brain cortical synaptosomes from adult male Sprague-Dawley rats were prepared according to the method previously described ${ }^{43}$. All animal experiments were carried out in accordance with the European Communities Council Directive (2010/63/EU) and the ARRIVE guidelines for the care and use of laboratory animals and the Danish legislation regulating animal experiments. Modulation of $\left[{ }^{3} \mathrm{H}\right]$ muscimol binding to rat brain cortical homogenate of AGO and its main compounds (dissolved in DMSO) were compared. DMSO was used as a vehicle control. On the day of the assay, the membranes were quickly thawed in binding buffer ( $50 \mathrm{mM}$ Tris- $\mathrm{HCl}$ buffer; $\mathrm{pH} 7.4$ ), then homogenized and washed three times by centrifugation $\left(48,000 \times \mathrm{g}\right.$ at $\left.4{ }^{\circ} \mathrm{C}\right)$. The $\left[{ }^{3} \mathrm{H}\right]$ muscimol binding assay was performed in a 96-well format essentially as previously described ${ }^{43,44}$. For this purpose, aliquots of membrane preparation (75-100 $\mu \mathrm{g}$ protein/aliquot) were incubated with a test substance and radioligand 
$\left[{ }^{3} \mathrm{H}\right]$ muscimol $(5 \mathrm{nM})$ in a total volume of $250 \mu \mathrm{L}$ at $0^{\circ} \mathrm{C}$ for $60 \mathrm{~min}$. Nonspecific binding was determined in the presence of $1 \mathrm{mM}$ GABA whereas $100 \mu \mathrm{M}$ diazepam was used as a control for positive modulation. After incubation for $1 \mathrm{~h}$ at $0-4^{\circ} \mathrm{C}$, the binding reaction was terminated by rapid filtration through GF/C unifilters (PerkinElmer) using a 96-well Packard FilterMate cell harvester, followed by three successive washes with ice-cold binding buffer, the addition of Microscint scintillation fluid (PerkinElmer) and quantification of the filter-bound radioactivity in a Packard TopCount microplate scintillation counter. The experiments were performed in triplicate and repeated in at least three independent experiments. Data analysis was performed using GraphPad Prism 7.0b (GraphPad Software Inc, La Jolla, CA, USA). Counts per min values were converted to specific binding by subtracting non-specific binding. For modulation curves, data were fitted by non-linear regression analysis using the equation for sigmoidal concentrationresponse with variable slope as follows (1):

$$
\mathrm{Y}=\text { Bottom }+(\text { Top }- \text { Bottom }) /\left(1+10^{\wedge}\left(\left(\log \mathrm{IC}_{50}-\mathrm{X}\right) \mathrm{x} \text { Hill-Slope }\right)\right)
$$

296

297

298

299

300

301

302

303

304

305

306

307

308

309

310

311

312

313

314

315

316

317

318

319

320

321

322

where $\mathrm{Y}$ is the response, $\mathrm{X}$ is the logarithm of the concentration, Top and Bottom are the plateaus in same units as $\mathrm{Y}$, and $\log \mathrm{IC}_{50}$ is the concentration giving a response halfway between Bottom and Top. The HillSlope is the steepness of the curve. All data were determined in triplicate and repeated in at least three independent experiments (as denoted in the figure legends).

Cytotoxicity study on PBMCs. The potential toxicity of AGO and blank NE-AGO on normal cells was assessed by a cytotoxicity test against human PBMCs. An MTT assay was used according to previous report with some modifications ${ }^{36,45}$. This study was approved by the Ethics Committee, Faculty of Associated Medical Sciences, Chiang Mai University (No. AMSEC-64EM-002. Informed consent was waived by the Ethics Committee of this Faculty of Associated Medical Sciences because all samples were anonymous. The research presents no more than minimal risk of harm to subjects and involves no procedures. Briefly, blood samples were collected by venipuncture from healthy volunteers and transferred into $15 \mathrm{~mL}$ of heparin-coated test tubes. Blood was diluted at a 1:1 ratio (v/v) with $0.1 \mathrm{M}$ PBS and layered onto Lymphoprep at a volume ratio of 3:1. PBMCs were collected after centrifugation at $1000 \times \mathrm{g}$ for $30 \mathrm{~min}$ and then washed 3 times with PBS. The PBMCs were resuspended in complete RPMI 1640 culture medium supplemented with $10 \% \mathrm{FBS}, 100 \mathrm{unit} / \mathrm{mL}$ of penicillin, $100 \mu \mathrm{g} / \mathrm{mL}$ of streptomycin, and $1 \mathrm{mM}$ of Lglutamine. The PBMCs were seeded in a 96-well tissue culture plate $\left(1 \times 10^{5}\right.$ cells/well $)$ and incubated at $37^{\circ} \mathrm{C}, 5 \% \mathrm{CO}_{2}$ atmosphere, and $95 \%$ relative humidity for $24 \mathrm{~h}$. After the incubation, various concentrations of AGO or blank NE-AGO in DMSO $(15-500 \mu \mathrm{g} / \mathrm{mL})$ in a complete RPMI 1640 culture medium $(100 \mu \mathrm{L})$ were added into each well and incubated for another 1, 3, 6, 12, 24, and $48 \mathrm{~h}$ for AGO and $48 \mathrm{~h}$ for blank NE-AGO. A mixture composed of 0.5\% v/v DMSO in a complete RPMI 1640 culture medium was used as a vehicle control. MTT stock dye solution ( $5 \mathrm{mg} / \mathrm{mL}$ MTT dye in PBS) was added to each well $(15 \mu \mathrm{L})$ after removal of $100 \mu \mathrm{L}$ of the medium, and the plate was incubated at $37^{\circ} \mathrm{C}$ in a $5 \% \mathrm{CO}_{2}$ atmosphere. After $4 \mathrm{~h}$, the supernatant was removed, followed by the addition of DMSO $(200 \mu \mathrm{L})$ to each well and mixed thoroughly to dissolve the dye crystals. Absorbance was measured using an AccuReaderTM M965/965+ microplate reader (Metertech Inc., Taiwan) at $570 \mathrm{~nm}$ with a reference wavelength of $630 \mathrm{~nm}$. All experiments were performed in triplicate and at least three independent experiments confirming the data. The percent of cell viability was calculated using the following equation (2):

$\%$ Cell viability $=($ MAtest $/$ MAcontrol $) \times 100$ 
where MAtest and MAcontrol are mean absorbance in test wells and mean absorbance in vehicle control wells.

Statistical analysis. The data are presented as mean \pm S.E.M. Statistical evaluation of cytotoxicity study was performed by a one-way ANOVA followed by Tukey's posthoc or Dunnete's test where $p<0.05$ was considered to indicate significant differences.

\section{References}

1. Prakatthagomol, W., Sirithunyalug, J. \& Okonogi, S. Comparison of antibacterial activity against foodborne bacteria of Alpinia galanga, Curcuma longa, and Zingiber cassumunar. Chiang Mai University Journal of Natural Sciences 11, 177-186 (2012).

2. De Pooter, H. L., Omar, M. N., Coolsaet, B. A. \& Schamp, N. M. The essential oil of greater galanga (Alpinia galanga) from Malaysia. Phytochemistry 24, 93-96 (1985).

3. Chudiwal, A. K., Jain, D. P. \& Somani, R. S. Alpinia galanga Willd.- An overview on phytopharmacological properties. Indian Journal of Natural Products and Resources 1, 1 143-149 (2010).

4. Satish, R. \& Dhananjayan, R. Evaluation of anti-inflammatory potential of rhizome of Alpinia galanga Linn. Biomedicine 23, 91-96 (2003).

5. Acharya, S. D. et al. Analgesic effect of extracts of Alpinia galanga rhizome in mice. J. Chinese Integr. Med. 9, 100-104 (2011).

6. Khumpirapang, N., Klayraung, S., Tima, S. \& Okonogi, S. Development of microemulsion containing alpinia galanga oil and its major compounds: enhancement of antimicrobial activities. Pharmaceutics vol. 13 (2021).

7. Khumpirapang, N., Pikulkaew, S., Müllertz, A., Rades, T. \& Okonogi, S. Self-microemulsifying drug delivery system and nanoemulsion for enhancing aqueous miscibility of Alpinia galanga oil. PLoS One 12, e0188848 (2017).

8. Khumpirapang, N., Pikulkaew, S., Anuchapreeda, S. \& Okonogi, S. Alpinia galanga oil-A new natural source of fish anaesthetic. Aquac. Res. 49, 1546-1556 (2018).

9. Santos, F. A. \& Rao, V. S. N. Antiinflammatory and antinociceptive effects of 1, 8-cineole a terpenoid oxide present in many plant essential oils. Phyther. Res. 14, 240-244 (2000).

10. De Araújo, F. Y. R. et al. Central nervous system effects of the essential oil of the leaves of Alpinia zerumbet in mice. J. Pharm. Pharmacol. 61, 1521-1527 (2009).

11. Carlini, E. A., Dallmeier, K. \& Zelger, J. L. Methyleugenol as a surgical anesthetic in rodents. Experientia 37, 588-589 (1981).

12. Cheng, S. S., Yeh, J. \& Flood, P. Anesthesia Matters: Patients Anesthetized with Propofol Have Less Postoperative Pain than Those Anesthetized with Isoflurane. Anesth. Analg. 106, 264-269 (2008).

13. Garcia, P. S., Kolesky, S. E. \& Jenkins, A. General anesthetic actions on GABA A receptors. Curr. Neuropharmacol. 8, 2-9 (2010).

14. Hall, A. C. et al. Modulation of human $\mathrm{GABA}_{\mathrm{A}}$ and glycine receptor currents by menthol and related monoterpenoids. Eur. J. Pharmacol. 506, 9-16 (2004).

15. Sanna, E., Garau, F. \& Harris, R. A. Novel properties of homomeric beta 1 gamma-aminobutyric acid type A receptors: actions of the anesthetics propofol and pentobarbital. Mol. Pharmacol. 47, 213-217 (1995).

16. Thyagarajan, R., Ramanjaneyulu, R. \& Ticku, M. K. Enhancement of Diazepam and $\gamma$-Aminobutyric Acid Binding by (+) Etomidate and Pentobarbital. J. Neurochem. 41, 578-585 (1983).

17. Tomlin, S. L., Jenkins, A., Lieb, W. R. \& Franks, N. P. Stereoselective effects of etomidate optical isomers on gamma-aminobutyric acid type A receptors and animals. J. Am. Soc. Anesthesiol. 88, 708717 (1998). 
18. Has, A. T. C. et al. The inhibitory activity of nutmeg essential oil on $\mathrm{GABA}_{A} \alpha 1 \beta 2 \gamma 2 \mathrm{~s}$ receptors. Biomed. Res. 25, 543-550 (2014).

19. Perumalla, A. V. S. \& Hettiarachchy, N. S. Green tea and grape seed extracts - Potential applications in food safety and quality. Food Res. Int. 44, 827-839 (2011).

20. Khumpirapang, N., von Gersdorff Jørgensen, L., Müllertz, A., Rades, T. \& Okonogi, S. Formulation optimization, anesthetic activity, skin permeation, and transportation pathway of Alpinia galanga oil SNEDDS in zebrafish (Danio rerio). Eur. J. Pharm. Biopharm. 165, 193-202 (2021).

21. Okonogi, S. et al. Development of Self-nanoemulsifying drug delivery Systems containing 4allylpyrocatechol for treatment of oral infections caused by Candida albicans. Pharmaceutics vol. 13 (2021).

22. Stylios, G. K., Giannoudis, P. V \& Wan, T. Applications of nanotechnologies in medical practice. Injury 36, S6-S13 (2005).

23. Bhargava, K., Conti, D. S., da Rocha, S. R. P. \& Zhang, Y. Application of an oregano oil nanoemulsion to the control of foodborne bacteria on fresh lettuce. Food Microbiol. 47, 69-73 (2015).

24 Kheawfu, K., Pikulkaew, S., Hamamoto, H., Sekimizu, K. \& Okonogi, S. Influence of clove oil and eugenol on muscle contraction of silkworm (Bombyx mori). Drug Discov. Ther. 11, 64-69 (2017).

25. Kheawfu, K., Pikulkaew, S., Rades, T., Müllertz, A. \& Okonogi, S. Development and characterization of clove oil nanoemulsions and self-microemulsifying drug delivery systems. J. Drug Deliv. Sci. Technol. 46, 330-338 (2018).

26. Anuchapreeda, S., Fukumori, Y., Okonogi, S. \& Ichikawa, H. Preparation of lipid nanoemulsions incorporating curcumin for cancer therapy. J. of nanotechnology. 2012, 1-11 (2012).

27. de Vasconcelos Silva, M. G., Craveiro, A. A., Matos, F. J. A., Machado, M. I. L. \& Alencar, J. W. Chemical variation during daytime of constituents of the essential oil of Ocimum gratissimum leaves. Fitoterapia 70, 32-34 (1999).

28. Faridah, Q. Z., Abdelmageed, A. H. A., AN, N. H. \& Yaacob, M. Comparative study of essential oil composition of leaves and rhizomes of Alpinia conchigera Griff. at different post-harvest drying periods. J. Med. Plants Res. 4, 2700-2705 (2010).

29. Song, R. et al. Preparation and characterization of an oil-in-water microemulsion of thiamethoxam and acetamiprid without organic solvent for unmanned aerial vehicle spraying. Colloids Surfaces A Physicochem. Eng. Asp. 607, 125485 (2020).

30. Debnath, S., Satayanarayana \& Kumar. Nanoemulsion-A Method to Improve The Solubility of Lipophilic Drugs, Pharmanest. 2, 72-83 (2011).

31. Aktaş, Z. Effect of non-ionic reagent adsorption on zeta potential of fine coal particles. Turkish J. Chem. 24, 117-130 (2000).

32. Marinova, K. G. et al. Charging of oil-water interfaces due to spontaneous adsorption of hydroxyl ions. Langmuir 12, 2045-2051 (1996).

33. Falk-Petersen, C. B. et al. Discovery of a new class of orthosteric antagonists with nanomolar potency at extrasynaptic GABA receptors. Sci. Rep. 10, 1-12 (2020).

34. Tan, K. R., Baur, R., Charon, S., Goeldner, M. \& Sigel, E. Relative positioning of diazepam in the benzodiazepine-binding-pocket of GABA A receptors. J. Neurochem. 111, 1264-1273 (2009).

35. Khumpirapang, N. et al. In vivo anesthetic effect and mechanism of action of active compounds from Alpinia galanga oil on Cyprinus carpio (koi carp). Aquaculture 496, 176-184 (2018).

36. Okonogi, S., Duangrat, C., Anuchpreeda, S., Tachakittirungrod, S. \& Chowwanapoonpohn, S. Comparison of antioxidant capacities and cytotoxicities of certain fruit peels. Food Chem. 103, 839846 (2007).

37. Liu, C. P. et al. The extracts from Nelumbo nucifera suppress cell cycle progression, cytokine genes expression, and cell proliferation in human peripheral blood mononuclear cells. Life Sci. 75, 699-716 
(2004).

38. Anazetti, M. C., Melo, P. S., Durán, N. \& Haun, M. Comparative cytotoxicity of dimethylamidecrotonin in the promyelocytic leukemia cell line (HL60) and human peripheral blood mononuclear cells. Toxicology 188, 261-274 (2003).

39. Ding, J. et al. Electrophysiological Characterization of Methyleugenol: A Novel Agonist of GABA(A) Receptors. ACS Chem. Neurosci. 5, 803-811 (2014).

40. Ferreira-da-Silva, F. W., da Silva-Alves, K. S., Alves-Fernandes, T. A., Coelho-de-Souza, A. N. \& Leal-Cardoso, J. H. Effects of 1, 8-cineole on $\mathrm{Na}^{+}$currents of dissociated superior cervical ganglia neurons. Neurosci. Lett. 595, 45-49 (2015).

41. Kawaree, R., Okonogi, S., Chowwanapoonpohn, S. \& Phutdhawong, W. Chemical composition and antioxidant evaluation of volatile oils from Thai medicinal plants. in International Workshop on Medicinal and Aromatic Plants 786 209-216 (2007).

42. Okonogi, S. \& Chaiyana, W. Enhancement of anti-cholinesterase activity of Zingiber cassumunar essential oil using a microemulsion technique. Drug Discov. Ther. 6, 249-255 (2012).

43. Ransom, R. W. \& Stec, N. L. Cooperative modulation of $\left[{ }^{3} \mathrm{H}\right] \mathrm{MK}-801$ binding to the N-methyl-daspartate receptor-ion channel complex by l-glutamate, glycine, and polyamines. J. Neurochem. 51, 830-836 (1988).

44. Karim, N. et al. 3-Hydroxy-2'-methoxy-6-methylflavone: a potent anxiolytic with a unique selectivity profile at $\mathrm{GABA}_{\mathrm{A}}$ receptor subtypes. Biochem. Pharmacol. 82, 1971-1983 (2011).

45. Khonkarn, R., Okonogi, S., Ampasavate, C. \& Anuchapreeda, S. Investigation of fruit peel extracts as sources for compounds with antioxidant and antiproliferative activities against human cell lines. Food Chem. Toxicol. 48, 2122-2129 (2010).

\section{Acknowledgments}

The authors are thankful for financial, facility, and instrument support received from Faculty of Health and Medical Sciences, University of Copenhagen, and the Research Center of Pharmaceutical Nanotechnology, Chiang Mai University.

\section{Author contributions}

Conceptualization, A.M., T.R., and S.O.; methodology, N.K., S.A., and P.W.; investigation, N.K. and P.W.; data curation, N.K. and P.W.; data analysis and interpretation, N.K., P.W., S.A., S.O., A.M., T.R., and K.S; writing-original draft, N.K.; writing-review and editing: P.W., A.M., T.R., S.O. All authors have read and agreed to the published version of the manuscript.

\section{Institutional Review Board Statement}

The study was conducted according to the guidelines of the Declaration of Helsinki and approved by the Ethics Committee of Faculty of Associated Medical Sciences, Chiang Mai University (protocol code AMSEC-64EM-002).

\section{Competing interests}

The authors declare no competing interests. 


\section{Supplementary Files}

This is a list of supplementary files associated with this preprint. Click to download.

- GraphicAbsttract.png 